\title{
Book Review: The Imperial Mode of Living: Everyday Life and the Ecological Crisis of Capitalism by Ulrich Brand and Markus Wissen
}

\author{
Jamie Ranger
}

St. Hugh's College, University of Oxford, Oxford, UK, james.ranger@st-hughs.ox.ac.uk, jayranger@hotmail.co.uk

\begin{abstract}
Jamie Ranger reviews Ulrich Brand and Markus Wissen's 2021 book The Imperial Mode of Living: Everyday Life and the Ecological Crisis of Capitalism. The book explores the extent to which everyday practices of consumption in the global North rely on the exploitation of resources and labour from 'somewhere else' (an intentionally vague reference to the global South) and as such hide the broader paradox at the heart of the expansion of western standards of living across the world: the more globally accessible the standard of living becomes, the more economically exploitative and ecologically unsustainable it is for those not privy to its comforts.
\end{abstract}

Keywords: imperial mode of living, green capitalism, anti-imperialism, exploitation, global South

Acknowledgement: Thanks to Christian Fuchs for arranging a review copy.

\section{Introduction}

To what extent are those of us living with the everyday comforts and securities of the global North implicated in the broader economic practices of exploitation in the global South? Furthermore, if we are the indirect beneficiaries of broader systems at play that are largely beyond our control, how may we think globally and inclusively to better understand these issues, often misunderstood as individual ethical dilemmas, to find collective political solutions?

Ulrich Brand and Markus Wissen's 2021 book The Imperial Mode of Living: Everyday Life and the Ecological Crisis of Capitalism explores the extent to which everyday practices of consumption in the global North rely on the exploitation of resources and labour from 'somewhere else' and as such hide the broader paradox at the heart of the expansion of western standards of living across the world: the more globally accessible the standard of living becomes, the more economically exploitative and ecologically unsustainable it is for those not privy to its comforts.

As noted in the foreword by Liliane Danso-Dahmen of the Rosa Luxemburg Foundation, the concept of the imperial mode of living (or IML) is designed to "show the connections between global structures and globalised practices of everyday living" and create a "political-strategic proposal for connecting supposedly different struggles with one another" to "advance a great social-ecological transformation toward a solidary mode of living" (Brand and Wissen 2021, xiii). 


\section{Book Overview}

Chapter One, "At the Boundaries of a Mode of Living", begins with the geopolitical contention articulated by Robert D. Kaplan in 1994 that the Global North had abandoned the Global South since the end of the Cold War, and as such, that epidemics, failed states, ecological devastation and myriad tragedies were befalling populations suffering from the emergent intractable cultural and religious conflicts. Kaplan presents a fragmented, dysfunctional, "ungovernable" situation in which the environment is framed as the national-security issue of the 21st century. Brand and Wissen acknowledge the plausibility of the hypothesis, but rightly contest the absence of social and material relations at the heart of the analysis. People don't just languish in poverty without context; they don't fight one another without political and social motivations; they cannot be oppressed without an oppressor; and to what extent is the Global North's governments turning their backs on the Global South merely a means by which the Global North's corporations can remain as influential and exploitative as they were when they functioned within colonial regimes?

Brand and Wissen present the reader with four purposes of the book: firstly, "to make visible the forces that facilitate the everyday life of production and consumption of people in the global North, as well as of a growing number of people in the global South, without necessarily passing the threshold of conscious perception or crossing into critical reflection" to show how "normality is produced precisely by masking the destruction in which it is rooted" (5). Secondly, to explore "how and why this sense of normality is produced in a time when problems and crises are accumulating, intensifying and overlapping in so many different areas" and to investigate the paradox of the IML: how it affects and exacerbates worldwide crises such as climate breakdown, global inequality and geopolitical tensions whilst somehow stabilising "social relations in the countries where its benefits are concentrated" (5). Thirdly, to show the way in which an economic system reliant on a burden being held "elsewhere" is incompatible with any rise in universal living standards: as the BRIC (Brazil, Russia, India, China) countries become competitors with the global North, "fewer and fewer people in the global South will be prepared to risk their own lives" (6) for the sake of maintaining the global North's living standards. Fourthly, such an economic diagnosis calls for a political intervention: "the ecological crisis must be recognised for what it is: a clear indication that the global North's norms of production and consumption, which evolved with capitalism and have now become universal, can be maintained in their ecologically modernised form only at the cost of ever more violence, ecological destruction and human suffering, and, at that, in an ever-smaller part of the world" (8).

In Chapter Two, "Multiple Crises and Socio-ecological Transformation", the reader is introduced to the contradictions of environmental politics. The 1990s was dominated by the rhetoric of "sustainable development", of myriad international conferences, committees, reports and organisations all fundamentally in service of "market mechanisms for fighting the ecological crisis" (15), a crisis that many state actors were more than happy to continue downplaying for ideological and, of course, financial reasons. After the crisis of 2008, business pivoted to environmental policy as a liberal veneer to cover for their otherwise systemically unaccountable transgressions. Furthermore, the rise of the global South's economic productivity corresponded to rises in levels of carbon dioxide emissions and general pollution levels in absolute numbers (if not per capita) and as such, the global North could portray themselves as the liberal, well-meaning protagonists in a 'save-the-planet' story whilst being given political licence to discipline their newly emboldened competitors. The vague language of "transformations towards sustainability" (24) hides all manner of geopolitical and economic vested interests, as 
well as serving to water down any substantive proposals, dousing any radical policy suggestions with what appears to be the pragmatism of technical specialists. Furthermore, the entire debate too often leads to the perspective of "the education of princes", that "instead of starting a fight with the elites to take away their privileges and limit their power, these elites must be convinced of the right thing to do" (25). This notion chimes well with the centrist response to political demands from the left: tell us what you want, vote us in and we might do it, explain to us what you want but do not let anyone else take the position of deciding whether and when to enact what you want. The capitulation of the left to the centre, only to find their demands unmet or outright mocked from 'moderates' in power, has been politically suicidal for a generation.

The authors also note the importance of ensuring that the political responsibility of state actors and corporations is not projected back onto individual consumers without a structural analysis: after all, "humankind" is a vulgar abstraction that occludes the social mediation of the human impact on the environment "through relations of power, class, gender and 'race'" (28). The necessary political and economic changes required to avert climate breakdown places the needs of all in conflict with the short-termism and ideologically entrenched convictions of a privileged few: "the prospect socio-ecological transformation thus crucially implies pitting ourselves against various powerful economic and political actors that have little or no interest in a wide-reaching change" (34).

In Chapter Three, "The Concept of the IML", the authors introduce the core idea that "everyday life in the capitalist centres is essentially made possible by shaping social relations and society-nature relations elsewhere, i.e., by means of (in principle) unlimited access to labour power, natural resources and sinks - ecosystems (such as rainforests and oceans) [...] on a global scale" (40-41). The author use "elsewhere" flippantly with intention: we don't care where our underwear was made, nor our morning coffee; we don't pay attention to where the materials that went into our computers came from, as long as it's here and it's working, and we've got a decent Wi-Fi connection. Moreover, even an individual taking a unique and profound interest in the sourcing of their everyday products, the logic of ethical consumerism, does little to combat broader structural issues. After all, states turn us into habitual recyclers whilst giving tax breaks to companies that spill their oil in the ocean. The authors attribute their concept to a Gramscian approach, in finding the hegemonic mode in which certain social practices are normalised and 'naturalised' As anyone with a background in sociology may suspect, it is not long before the authors invoke the work of Pierre Bourdieu (and his notion of habitus) in mapping the everyday lifestyle choices, perceptions and guiding themes that reproduce the imperial mode of living. The authors isolate "the pre-eminence of consumerism, eating meat and private car ownership" (45) as examples. The IML is described as "both necessity and promise, constraint and precondition for life and social participation" (54). The claim is that "the experience of inequality opens up a space for social and political confrontations over alternatives" (59), but like any hegemonic mode of living, it is adaptable and resilient: the IML is becoming "greener" in terms of refocusing on sustainability, inclusive economic growth and rhetorical commitment to fighting climate breakdown, and yet its self-revolutionising will always ensure that its essential features remain intact (67).

Brand and Wissen concede that the fourth chapter, "The Historical Making of the IML", could be a monograph on its own, given the extensive history of colonial 
exploitation of the global South by the North. ${ }^{1}$ The authors chart the European powers, their colonial expansion, the extent to which their policies were determined by their hunger for certain resources: beginning initially as a system designed to furnish the upper classes with luxury goods, the colonial production of food products became an important means of 'democratising' (to use the word ignobly) the imperial mode of living, especially in Britain, as rich and poor alike benefited from the importation of sugar. Nevertheless, despite industrialisation, technological innovation and the unprecedented flow of wealth, resources, and goods into the European powers, "free market capitalism was accompanied by catastrophic living and working conditions for most people, not just in the colonies, but in the centres as well" (88).

Moving forward to American consumerist expansion and the US economic boom of the 1940s, the authors account for the "emergence of 'modern' and 'western' consumption norms" (91) and the oft-forgotten heavy-handedness of ideological Fordism: "Henry Ford ran his own 'Sociological Department', which subjected his workers to rigorous control" (93), managing their drinking, smoking, frugality, and even expecting their betrothed to make good housewives. Here already the authors are illustrating the connection between the automotive industry and the IML, best encapsulated by the apocryphal Margaret Thatcher quote that "anyone riding the bus over the age of 26 can consider themselves a failure in life".

The authors contend that "a fundamental part of the dominant Western world view was the idea that 'society' could increasingly be emancipated from 'nature', or from the constraints of nature, through technological and scientific innovations" (95-96), a notion that underpins critical theory as well as ecological and economic analysis of our contemporary situation. As Brand and Wissen convincingly argue, in practice, the western world did not emancipate itself from nature; rather, it externalised the "consequences of extremely destructive society-nature relations" (96). Furthermore, the incredibly costly mode of living in the global North tended to require nondemocratic actors in the global South, with the former lobbying and supporting conservative and authoritarian political actors to ensure there was no clamour for the improvement of working conditions, nationalisations of key industries, or any other pesky disruptions to the flow of resources upward. "In the 1970s, as the Fordist period drew to a close, the imperial mode of living became caught up in its own crisis - while remaining attractive and expansive" (99): all that blood spilled, the revolutions curtailed, the racism propagated, the property pillaged, for an unsustainable mode of living that had never proven so unstable and yet was also reaching the height of its popularity.

In Chapter Five, "The Global Universalisation and Deepening of the IML", the authors consider the OPEC crisis the historically missed opportunity for a radical redirection of the trajectory of geopolitical forces and international economic organisation. The opportunity was closed by neoliberal retrenchment on the part of the global North: international organisations such as the International Monetary Fund (IMF) became integral in reproducing the IML by burdening 'developing' (read: ransacked) countries with debt.

${ }^{1}$ If I have one criticism of this chapter, I found the lack of regional voices disappointing, especially given the extensive practical discussions of overhauling colonial resource management in the diaries of famous African revolutionaries. Nevertheless, it is hard to know the extent to which I may lay blame at the authors' feet. African writing has been left out of publication, is untranslated and is less publicised within the academy, perhaps for the very reasons that the book suggests: that such writing undermines the hegemonic articulation of the imperial mode of living. 
Furthermore, the emergence of the "information economy" in the west serves to mask the intensification of the consumption of resources such as oil (exacerbated among other things by cheap air travel) and dematerialises the risky business of obtaining rare earth metals, as well as dealing with electronic waste pollution (107). China and India are expected to require far more energy to hit their growth targets, and yet (forced by environmental necessity and geopolitical manoeuvring) the expectation will be that they adopt renewable energies or reduce their carbon footprints precisely when their economies approach the point of overtaking the west.

The authors consider China's expanding middle class, noticing that it is industrialisation and the expansion of consumer markets that have allowed a higher standard of living, but in the imperial mode. Despite Xi Jinping's efforts to impose environmental laws for a "Beautiful China" at the national level, the laws are "often disregarded, especially as a result of close connections between companies and Party cadres at the local level" (124), and so long as the nation meets its growth targets and the standard of living consistently improves over time, we have the historical lessons from colonial Europe and Fordist America that populations are happy to overlook structural issues when the going's good. The IML "promotes a specific relationship between the state and population - 'citizenship through consumption' - which promises greater opportunities for consumption in exchange for acceptance of the existing political and economic order" (127).

The authors undertake an overview of resource extraction in Latin America (124131 ), which calls to mind recent elections in the region. Could the imperial mode of living explain the voting allocation in recent South American elections in Bolivia and Peru? The diaspora and voters in the city, closer to systems of imperial production, vote overwhelmingly for openly fascistic, pro-America, authoritarian-minded politicians, whilst those rural areas most exploited by the systems of production and consumption vote overwhelmingly for openly pro-worker, pro-union, populist socialists, often with indigenous and working-class backgrounds. One could argue that the 'pink wave' is symptomatic of the broader encroaching crisis point of the IML outlined in the text as the inherent paradox of pushing for more of the world to raise its standards of living even though the standards of living are predicated on systemic exploitation of the developing world.

In Chapter Six, "Imperial Automobility", the authors return to their pet peeve: the SUV. The middle-class owners of these gas-guzzling automobiles are characterised as the epitome of the IML subjectivity, "the polarisation between security and insecurity, as well as between superiority and subalternity" (140): it is clear to the reader that the authors believe the SUV to be a frankly grotesque adoption of a polluting, individualising mode of transport that has been weirdly normalised. Perhaps this is where the IML's phenomenological dimension gets most of its attention: ultimately, the concept is more than simply elucidating the history of capitalist exploitation; it's also about making the present strange, making certain products, habits and choices that usually fade into the background feel absurd and unnecessary: "the development of ever faster and ever more high-performance vehicles can be understood as an attempt to minimise the loss of time through technological and competitive means: whoever can afford the most horsepower gets ahead in the rat race" (147).

In Chapter Seven, "False Alternatives: From the Green Economy to a Green Capitalism?", the authors begin to wrestle with the political complications of untethering the western standards of living from the exploitative structures that secure them. The emerging mainstream environmental political discourse is happy to talk about "transforming economies", but not underlying capitalist dynamics (161). The underlying 
assumption of any green capitalism is that "the necessary absolute reduction of resource consumption and the strain on sinks is feasible without challenging the imperial mode of living, the political economy of capitalism, or the relationships of social forces that sustain it" (161-162).

Despite paying lip service to sustainability and bringing supposed environmental externalities back into capitalism (through ideas such as carbon taxes), "what remains hidden is the fact that ecosystems are not destroyed because they lack a price tag that would quantify the cost of their destruction" (165): international organisations wish to play "tragedy of the commons" seminar room solutions with entire regions and communities, assuming the neutrality of the "state" and the "market" in a way that you can only really get away with precisely because you work in these aforementioned organisations. The authors suggest that at worst green capitalism will lead to "a new speculative (financial) market segment" developing with "inherent economic and ecological risks, because offset trading relies on continuing, rather than overcoming, the ecologically destructive imperial mode of living" (172). The authors contend that green capitalism will "neither effectively manage the ecological crisis nor reduce inequality, let alone create good living conditions for all; instead, it will generate and externalise new socio-ecological costs" (179).

In Chapter Eight, "Contours of a Solidary Mode of Living", the authors articulate their political project in response to the politics of "militarisation and securitisation" (185) that has been growing in prevalence, spurred on by the rhetoric of far-right parties across Europe. The authors contend that "changes to the imperial mode of living must begin at different points: it is about creating different political rules, social expectations and general approaches that push back against capitalist expansion and appropriation and make a solidary mode of living possible" (187). Is this not the individualist mode of politics symptomatic of green capitalism, rearticulated for a better economic vision? The authors bring in Foucault's form of practical criticism, conceding that his intended theory applied to individuals, and maintain that "it also applies to collective actors, such as trade unions and society as a whole" (188).

It is granted that for the IML to come to an end and a more solidary mode of living to take its place there must be an expanding of spaces and alliances "that enable emancipatory action" (189). The aim is a solidary mode of living, described as "just, democratic, peaceful and truly ecological - [a] model of prosperity beyond capitalist, patriarchal and racist impositions, beyond the domination and exploitation of nature" (193). The political aspiration is to link refugee solidarity movements with environmental activists, to support concerned mothers who don't want Coca Cola machines in their children's schools and ask them to think about whether they need a Range Rover, and so on. We ought to be campaigning for the democratisation of energy in the global North, but more importantly, to get out of the way of political actors trying to democratise their resources in the global South. A solidary mode of living "must recognise the fundamental vulnerability of human and nonhuman life and create forms of living together that are not based on making the lives of many or even only a few people precarious, or that similarly endanger nature" (199). It is a politics that acknowledges and takes responsibility for the Anthropocene.

In "An Afterword in Times of Corona", the authors retain a sense of optimism despite the horrors of the pandemic: the IML has been compromised by a global catastrophe, our lives are changed, and we have an opportunity to communicate a new vision for the world we want to 'return to' when the crisis ends. 


\section{Reflections}

In the context of this journal, we may wish to ask ourselves to what extent the "imperial mode of living" as a concept increases the capacity of socialist scholars to effectively communicate the systemic injustices produced by capitalism. I'd argue that the future of progressive electoral politics may be determined by the cohesiveness and coherence of a political project that accommodates Gen X centre-left party loyalists, Millennial left-populists and Gen Z's radical environmentalists, and the imperial mode of living may be a concept capable of bridging the rhetorical gap between 'stakeholder capitalist left-liberals' in starched collar shirts and 'ecologically conscious anti-capitalist' students with neon-coloured hair (aesthetic stereotypes subject to change). It is hard to ignore that whilst values of social liberalism have remained broadly consistent across the European left across the generational divides (with the huge and significant exception of transphobia), there has been much intergenerational discontinuity and discord caused by disagreements concerning economic issues. The IML forces a strategic rethink, a realignment of environmental policies against 'green capitalism' (and the racist overpopulation narratives and bad-faith propaganda of 'eco-fascism') that could provide a united front against predatory corporatism and right-wing culture wars (no doubt exacerbated by the expected increase in climate refugees).

Nevertheless, the political battle ahead of us appears complex, intricate, and vague: I completely agree that we need to respond to the emergence of the 'neoliberal, enabling and increasingly regressive state' by restructuring the state, but that is a project that has never been attempted in the global North without severe backlash and repercussions. Geopolitically speaking, would a country like Germany have to leave the G7, even NATO, to achieve this goal? Although the book is written by scholars intervening in a debate occurring within German domestic politics, the concept of the imperial mode of living is paradigmatic of the invisibility of sincere and historically informed colonial reckoning in British public life. At the time of writing, the latest YouGov polling shows that two thirds of Britons support cutting the foreign aid budget (Smith 2020), a paltry amount of money in the context of total state finances and an utterly measly sum in comparison to the calculated costs that Britain's imperial regime inflicted around the world, including on many of the countries currently receiving the aid in question. I suppose one of the more useful aspects of making visible the IML is exposing the pampered middle-class professionals who are perfectly aware that if they turned their heads in the right direction, they would become politically and ethically culpable: so they ensure that they don't.

Brand and Wissen certainly strike at the heart of the politics that undergirds certain ways of living: it's one thing to acknowledge that car ownership is steadily declining across generations but think of the hysterical outcry from the Home Counties if a British politician suggested that we need to pivot away from car ownership on environmental grounds! Furthermore, the more cynical reader of green capitalism would go as far as to argue that the new greenwashing projects of finance capitalism and the most rapacious of capitalist states is indeed the ethical pretext for forcing countries like China and India to bear the brunt of any newly emergent externalities, slowing down their growth and forcing developing countries that have escaped direct imperial control to pay for the continuation of the IML in the global North.

Here is where my pessimism exerts pushback: if we want collective political solutions that radically transform the global economic structure, why does Brand and Wissen's critique of the IML focus on everyday practices? Is there not an easy misreading of the IML as an argument against personal car ownership and other consumer choices? Perhaps the IML is most effective as an intergenerational bulwark: look at the 
way of life your parents fetishized, for the sake of the planet, for the sake of your soul, we cannot continue to live like this!

Without banging the revolutionary drum too hard, we've had global issues with the imperial mode of living, and they were traditionally confronted with anti-imperialist insurgencies that were themselves viciously overthrown, assassinated and demonised in western media. Why are we to assume the global North are the political protagonists? Perhaps the role of those in the imperial core ought to be to mitigate the excesses of our state actors by pressuring them into making concessions to the global South and ensuring our political representatives aren't interested in bloodlust when the next wave of workers' protests and collective bargaining occurs in those countries most affected by the IML. The strength of the concept is in revealing contradictory, unrealistic expectations for a particular kind of lifestyle, and how the far-right seize on the collective malaise to propose their own (racist and unhelpful) solutions.

We have already seen the coronavirus response make visible the contours of the $I M L$, as vaccine patents are defended even at the cost of thousands of lives, as the global North vaccinates its populations, throws money in the direction of its wealthy business owners, effortlessly nationalises entire sectors of the economy to keep everything ticking over, having spent a generation telling their citizens it was all too expensive, only for the global South to remain largely unaided, a gap opening up between those wealthy citizens happy to pay and even travel to get vaccinated, whilst militarised border patrols and police enforce lockdown measures with increasingly disproportionate (and unaccountable) force. If a political project that confronts the IML relies on international solidarity, it could be noted that we all have the pandemic in common, but it is experienced differently the world over, and we may say that the IML provides the qualitative dividing line that captures what side feels more secure than the other.

At the time of writing, it came to my attention that a law was recently proposed in the German government that would make corporations liable for any exploitation (in the sense of child labour or appalling working conditions, rather than the extraction of surplus-labour!) in their supply chains. After a publicised lobbying campaign, which included taking out full page advertisements in major newspapers, the bill was watered down and passed:

The "Act on Corporate Due Diligence in Supply Chains" will enter into force in 2023 and will initially cover companies with 3,000 or more employees, and from 2024 onwards companies with 1,000 or more employees. These companies must identify risks of human rights violations and environmental destruction at direct suppliers and, if necessary, also at indirect suppliers. They must take countermeasures and document them to the Federal Office for Economic Affairs and Export Control (BAFA), which can issue fines if companies violate their due diligence obligations (Business \& Human Rights Resource Centre 2021).

Nevertheless, the incident revealed two things; firstly, the imperial mode of living, at least in German politics, is increasingly becoming an active concern for political actors, and secondly, arguments to maintain the status quo rely exclusively on misinformation or ignorance. In this case the argument from the lobbyists was laughable, ostensibly that corporations having to check if children were being harmed in the making of their products would 'slow them down' to the extent that checking would be a costly waste of time, and that if any corporations were in fact using exploitative supply chains, it ought to be the job of governments in the Global South to admonish them, not the Global North. This form of lobbying backfires by highlighting precisely why corporations 
wish to rhetorically 'empower' the governments of the Global South: they know they are comparatively impotent, and it is often the corporations themselves, through the quasi-illegal flexing of their commercial muscles, their own localised corrupt practices, and their capacity to threaten local markets, that keep those governments impotent.

There is an epistemic (perhaps I mean something closer to agnotological?) aspect to the imperial mode of living: some people do not wish to know the truth of the systems of exploitation that their comparative comfort relies upon, and so will knowingly circumvent the possibilities of acquiring the knowledge that makes them culpable, which itself plausibly renders them ethically culpable, yet thanks to their democratic representations, they remain politically inert. After all, political figures are often at the forefront of denying the exploitation within the status quo, and those parties most responsible for reproducing it are happy, with a wink and a nod, to keep your secrets in order to keep the show on the road.

Brand and Wissen's text also forces internal retrospection to those committed to progressive electoral politics. To what extent shall the contemporary centre-left commit itself to a retrospective analysis of its own colonial activities? To what extent will the centre-left commit itself to anti-imperialist political stances in the future? The diaries of assassinated African leaders from across the continent are full of specific (violent) altercations between their political projects and rapacious corporations that were themselves glorified arms of a broader colonial regime of racism, violence, dispossession, and exploitation. Will the red-green coalition hold the next time the OAS cries foul? Furthermore, to what extent are the conditions raised by the imperial mode of living the articulation of a system of exploitation that subaltern voices have been trying to get Europeans to pay attention to for generations?

To conclude, The Imperial Mode of Living is a punchy, coherent, and persuasive narrative of capitalism, providing a language through which anti-capitalist action may articulate the global North's political culpability in economic exploitation in ecological terms without advocating for the greenwashing individualism that only serves to reinforce contemporary asymmetries of power. The Imperial Mode of Living may well become an invaluable linguistic, ideological, and empirical resource for future red-green political activism.

\section{References}

Brand, Ulrich and Markus Wissen. 2021. The Imperial Mode of Living: Everyday Life and the Ecological Crisis of Capitalism. London: Verso.

Business \& Human Rights Resource Centre. 2021. German Parliament Passes Mandatory Human Rights Due Diligence Law. 11 July. Accessed 15 June 2021. https://www.business-humanrights.org/en/latest-news/german-due-diligence-law/

Initiative Neue Soziale Marktwirtschaft. 2021. Supply Chain Act: More Bureaucracy, Fewer Rights. June 7. Accessed 15 June 2021. https://www.insm.de/insm/themen/sozialemarktwirtschaft/lieferkettengesetz-mehr-buerokratie-weniger-menschenrechte

Smith, Matthew. 2020. YouGov Polling: Two Thirds of Britons Support Cutting Foreign Aid Budget. November 25. Accessed 15 June 2021. https://yougov.co.uk/topics/politics/articles-reports/2020/11/25/two-thirds-britons-support-cutting-foreign-aidbud?utm source=twitter\&utm medium=daily agenda\&utm campaign=foreign aid cuts 


\section{About the Author}

Jamie Ranger

Jamie Ranger is a doctoral candidate at St. Hugh's College, University of Oxford in the Department of Politics \& IR. He writes on the politics of speed, technics, media, space and radical democratic theory. He tweets from @jamieandhisego. 